ROCZNIKI HUMANISTYCZNE

Tom LXVIII, zeszyt $3-2020$

DOI: http://dx.doi.org/10.18290/rh20683-2

ADRIANA GRZELAK-KRZYMIANOWSKA

\title{
LATIN AND GREEK IN CONTEMPORARY NAMES OF HUMAN MEDICINES ON THE POLISH MARKET
}

The research of Latin and Greek in contemporary trade names of human medicines belongs to a much discussed field of onomastics-chrematonymy - that is, the onymic material in the study of proper names of some industrial, handicraft, individual and serial products that are not permanently connected with a specific landscape, the so-called chrematonyms. ${ }^{1}$ It requires not only linguistic knowledge, but is tightly connected with other disciplines such as sociology, psychology, history, sciences or economics. The characteristic and important feature of these names is the fact that they are created on purpose and on demand responding to the markets' potential. There are many fields of life already discussed and analysed such as names of beers, teas, sweets, bottles, furniture, cheese, pharmacies and drugs and medical supplements in its general linguistic context and function. ${ }^{2}$ This

Dr Adriana GrzelaK-Krzymianowska-Department of Classical Philology, Faculty of Philology, University of Lodz, ul. Pomorska 171/173, 90-236 Łódź, e-mail: adriana.grzelak-krzymianowska @uni.lodz.pl; ORCID: 0000-0002-6584-3987.

${ }^{1}$ The term is also discussed in Aleksandra CIEŚLIKOWA, "Jakie korzyści daje onomastyce chrematonimia?," in Chrematonimia jako fenomen wspótczesności, edited by Maria Biolik and Jerzy Duma (Olsztyn: Wydawnictwo Uniwersytetu Warmińsko-Mazurskiego, 2011), 113-123; Edward BREZA, "Nazwy obiektów i instytucji związanych z nowoczesną cywilizacją (chrematonimy)," in Polskie nazwy własne. Encyklopedia, edited by Ewa Rzetelska-Feleszko (WarszawaKraków: Wydawnictwo Instytutu Języka Polskiego PAN, 1998), 343-361; Artur GAŁKowsKi, Chrematonimy w funkcji kulturowo-użytkowej. Onomastyczne studium porównawcze na materiale polskim, włoskim, francuskim (Łódź: Wydawnictwo Uniwersytetu Łódzkiego, 2008); Artur GAŁKOWSKI, "Chrematonimia w kulturze współczesnej," Onomastica 61, no 1(2017): 55-71.

${ }^{2}$ In her article, Samuela Tomasik analyzes the names of Polish medicines. The author focuses on naming conventions, providing an analysis of the word-formation structure of names, and also dealing with factors that play an important role in the choice of names. The analysed material is divided into four groups: 1 . Names with an element that is based on the name of the active substance used in a medicinal product, 2. names of medicines with the name of major organ systems, 3. names of medicines with the name of diseases, 4 . names of medicines with descriptions. See 
article aims to discuss the presence of Latin and Greek components in modern word-formation processes, such as compounding, derivation or blending in the field of drug-naming in Poland, paying particular attention to so-called trade names of products, which in a way are key for the marketing success of those products. ${ }^{3}$ First of all, this applies to over-the-counter drugs (OTC), sold without a prescription. Our discussion will also include a juxtaposition of Latin and Greek language elements with Polish and English pharmaconyms. Disappointing as it may seem, the marketing success is no doubt the main goal of pharmaceutical companies, so in their quest for ways to advance the volume of sales, they worked out some useful strategies, and the process of inventing and launching trade names has become by the same token a kind of art.

The topic seems very important as the developing pharmaceutical business, strong competition on the market and the increasing availability of medicinal products ${ }^{4}$ in highly-developed countries are the factors that on the one hand promote creativity, but on the other demand for critical and, above all, responsible use of language resources, in particular the time and place. This research is based on the Official Register of Medicinal Products admitted to trading in the Republic of Poland for 2018, authorised by the Office for Registration of Medicinal Products, Medical Devices and Biocidal Products. ${ }^{5}$ We start with a brief presentation of a few basic definitions and policies regarding the applicable rules in the field of product naming in Poland. Next, the demonstration of the forms of presence of Latin and Greek components is provided along with the limitations and problems that occur in the simple application of classical terminology. The final chapter is an attempt to discover some linguistic patterns and tendencies in the use of Latin and Greek in the brand names of medicinal products, and to see the omnipresence of classical words in contemporary times (though the Polish

Samuela TOMAsik, "Onomastyka w służbie zdrowiu, czyli o nazwach handlowych leków. Rekonesans badawczy," Acta Onomastica 54(2013): 256-271. The use of Latin and Greek components is mentioned but not discussed in detail by S. Tomasik.

${ }^{3}$ See Artur GAŁKOWSKI, "Funkcja marketingowa chrematonimów w przestrzeni gospodarczej," in Funkcje nazw własnych w kulturze i komunikacji, edited by Irena Sarnowska-Giefing, Mieczysław Balowski, Magdalena Graf (Poznań: Instytut Naukowo-Wydawniczy "Maiuscula," 2015), 177 -179.

${ }^{4}$ Medicinal products are available now in pharmacies, pharmaceutical points, shops, markets, petrol stations, and supermarkets.

${ }^{5}$ All the names of medicinal products cited in this article appear in the List of Medicinal Products for the year 2018 of the Office for Registration of Medicinal Products, Medical Devices and Biocidal Products (accessed: September 23, 2019, http://dziennikmz.mz.gov.pl/api/DUM_ MZ/201 8/23/journal/4509). 
market has developed its own Slavic medical terminology), and whether such names are always appropriate and comprehensible. ${ }^{6}$

\section{PHARMACEUTICAL MARKET IN POLAND}

There are an increasing number of pharmacies operating in Central Europe. ${ }^{7}$ In $2017,{ }^{8}$ in comparison to 2016 , the total value of the pharmaceutical market (segments: pharmacy $\mathrm{Rx}$ and $\mathrm{CH}$, hospital and mail order sales of e-pharmacies), calculated in retail prices, amounted to PLN 38.3 billion (nearly 9 billion EUR), which means an increase of $4.9 \%$ year to year (PLN 1.8 billion). The number of pharmacies also shows an upward trend. The table below presents the number of places where medicinal products are available, excluding hospitals and drugstores. ${ }^{9}$

\begin{tabular}{|l|r|r|r|r|r|}
\hline Specification & $\mathbf{2 0 1 3}$ & $\mathbf{2 0 1 4}$ & $\mathbf{2 0 1 5}$ & $\mathbf{2 0 1 6}$ & $\mathbf{2 0 1 7}$ \\
\hline Pharmacies & 12,221 & 12,438 & 12,740 & 13,104 & 13,338 \\
\hline Pharmacy shops & 1,284 & 1,309 & 1,299 & 1,316 & 1,284 \\
\hline $\begin{array}{l}\text { No. of people for one generally } \\
\text { available pharmacy }\end{array}$ & 2,851 & 2,799 & 2,738 & 2,665 & 2,628 \\
\hline
\end{tabular}

Owing to the advancing age of the Polish population, advertising and easier access to medicinal products, the quantity of medicinal products (so called OTC) sold in Poland is increasing. Pharmaceutical companies spend great amounts of money on advertising OTC products ${ }^{10}$ They compete not only in

\footnotetext{
${ }^{6}$ An interesting analysis of foreign names in Polish terminology can be found in Justyna Barbara WALKOWIAK, "Foreign branding in Poland. Chrematonyms and Anthroponyms," Proceedings of ICONN 2(2013): 218-227.

${ }^{7}$ There is still a noticeable and growing number of pharmacies operating in Poland, Romania, Bulgaria, Hungary, Czech Republic and Slovakia. According to PMR (a dedicated team of market research and analysis experts specialising in Central and Eastern Europe) the most substantial number of pharmaciesin CE, 14,600, i.e., over $40 \%$ of the total, is located in Poland (accessed: April 29, 2019, https://www.thepharmaletter.com/article/growing-number- of- pharmacies-operatingin-central-europe-but-market-conditions-difficult).

${ }^{8}$ The annual report for 2018 is not available yet (http://www.urpl.gov.pl/en/office/annual-report).

${ }^{9}$ See (accessed: April 29, 2019), http://www.europeanpharmacistsforum.com. A slight decline was observed in 2018 due to new regulations (accessed: September 23, 2019, https://grantthornton.pl/wpcontent/uploads/2019/02/Rynek-apteczny-w-Polsce-RAPORT-Grant-Thornon-13-02-2019.pdf), but by 2023 a 5\% per annum increase is forecast (accessed: September 23, 2019, https://www.infobroker ska.pl/rynek-farmaceutyczny-w-polsce/).

${ }_{10}$ Accessed: September 23, 2019, https://www.kierunekfarmacja.pl/artykul,60604,aport-imm-bran za-farmaceutyczna-wydala-4-mld-215-mln-na-reklame-w-2018-roku-i-jest-liderem-zestawi enia.html.
} 
the means of production and distribution. In this race for profits, the names of medicines play an important role. It seems, then, that in order to attract customers drug names should be catchy, understandable, and first of all easy to remember.

\section{BASIC DEFINITIONS}

The definition of the medicinal product is included in the Pharmaceutical Law (See Journal of Laws 2001 No. 126, item 1381. Act of 6 September 2001, Pharmaceutical Law. Chapter 1, General Provisions). Medicinal product is ,a substance or mixture of substances presented as having the property of preventing or treating diseases affecting humans or animals or given for the purpose of diagnosis or to restore, correct or modify physiological functions of the body by pharmacological, immunological or metabolic action." A marketed drug always has three names: chemical name, generic or international name and trade or brand name. A chemical name is decided on the basis of the chemical structure of the drug and is used primarily in the science world. The chemical name is long and usually difficult to pronounce and remember; consumers, physicians and pharmacists are therefore better served by referring to the drug's generic name. A generic name is the official name of the drug all over the world regardless of who made it, how it was made, where it was developed. The generic name is commonly used by health care professionals and is usually created when a new drug is ready to be marketed. The generic name is always in the public domain and there is no need to use such letters as TM or ${ }^{\circledR}$ or $(C)$ with generic names. Once the drug's patent expires, other manufacturers may make the drug, referring to it by its generic name. The most important criterion considered when issuing a generic name is the usefulness of that name to health care providers. The name cannot be misleading or confusing; prefixes implying a general descriptive adjective, such as "new" or "improved," are not acceptable, nor are prefixes suggesting the manufacturer's name or an anatomical designation. The stem (a word common to members of a related group of drugs based on their use) is included so that shared characteristics (such as pharmacologic action) can be identified. ${ }^{11}$

${ }^{11}$ For further information, see Amit Gangwal, "Naming of Drug Molecules and Pharmaceutical Brands," accessed: April 29, 2019, https://www.pharmatutor.org/articles/naming-of-drugmole cules-and-pharmaceutical-brands. 
Although the generic name is in the public domain, the trade name is owned by the manufacturer and can be created as soon as the generic name has been approved. Unlike generic names, the choice of the trade name is motivated by marketing considerations and so the trade name is the sole responsibility of the manufacturer. ${ }^{12}$ The trade name is chosen by the company that wants to market the product and it is a marketing decision; however, it must be approved by the appropriate national or international council.

\section{MEDICINE TRADE NAMES-RULES AND LIMITATIONS}

There are rules and regulations regarding the names of medicinal products. According to the Announcement of the President of the Office for Registration of Medicinal Products, Medical Devices and Biocides from March 12, 2008, the name of the medicinal product:

- may be a proper name or a commonly used or scientific name together with the trademark or name of the responsible entity;

- should differ by at least three letters from the names of previously registered medicinal products and must not contain sequences of more than two of the same letters;

- should not be misleading or overstated in any way with regard to the therapeutic effect or the chemical composition;

- should also not create a risk of confusion in print, spelling and pronunciation as well as in the way of administration, indications for use with another name of a medicinal product already authorized for sale;

- should not convey any advertising or promotional content relating to its use. In the case of medicines with an accessibility category: "nonprescription drug," the invented product name may be informative;

- should not contain single digits, letters, or symbols, as this may be misleading in relation to the dose of the medicinal product, the method of dosage and duration of therapy. (The above notation may not apply to vaccines, radio-pharmaceuticals and immunological preparations.);

- must not contain first names and surnames, including names of drug discoverers, names of fictitious forms with scientific degrees and pseudonyms (it is acceptable for dietary supplements), as well as terms referring to

${ }^{12}$ On trade names and their meaning, see Giampaolo FABRIS and Laura MiNESTRONI, Valore e valori della marca. Come costruire e gestire una marca di successo (Milano: Franco Angeli, 2004), 214-256. 
religious associations, geographical, historical and natural names, as well as obscene, suggestive or indecent words.

The method of naming a new medicinal product depends primarily on its availability - on whether the drug will be issued without prescription or with prescription. The names of non-prescription medicinal products are targeted directly to consumers. They should be easy to remember, associated with the ailment they treat and suggest the route of administration of a given substance. Trade names of prescription medicinal products are not usually a tool for fighting for clients (they do not have to contain elements of advertising), because they are usually legible and easy to remember only for doctors. In addition, the name of the prescription medicine should give the physician information on the active substance in drug, be easy to remember and should not cause confusion, i.e. should not be associated with the names of other products. A similar situation is at stake regarding the medicinal products issued without prescription. Also in this case must the drug naming parties obey some rules. The main and the most important one seems that they should not cause confusion. Distinctiveness is another criterion that come to my mind as a potential consumer, which seems crucial in order to achieve market success. Language neutrality, economy and productivity, despite seeming of secondary importance, are not to be disregarded. And here come Latin and Greek with their much alike features.

\section{THE PRESENCE OF LATIN AND GREEK IN BRAND NAMES OF MEDICINAL PRODUCTS-ANALYSIS}

Within the trade names of medicinal products we may distinguish three main categories, in which Latin and Greek components occur. These are names that originate from the names of active substance present in the medicinal product; names associated with the name of the organ within which the medicinal product is active; names combined with an ailment that is healed by the given medicinal product.

1. The trade names that originate from the name of active chemical or herbal substance present in the medicinal product

Among the trade names of medicinal products that originate from the active substance there appear names that are proper names of different 
substances that were used to create a given product e.g. Acidum folicum, Furosemidum, or Adrenalina. ${ }^{13}$ There are many descriptive names in which the proper name of the herb or other plant in the genitive singular is accompanied by the form of obtaining the medicine, e.g., Intractum Melissae, Intractum Hyperici, Sirupus Pini, Tinctura Calendulae, Tinctura Salviae. This group also includes derivative forms of the names of medicines, e.g., Melissed. Composite words in the form of compound and blend words constitute the majority of the names of medicines. The most typical names include two joined components, which are either formed by two components combined from the beginnings of two words make=ing the proper name of one herbal or chemical substance, e.g., Echinapur [Echinacea purpurea] or combination of the beginning of one word and the stem of the other e.g. Mentowal [Menthyli isovaleras]. They may be formed by components taken from names of two different substances that operate in a given product either by joining two beginnings of words e.g. Rutinosal [ $\underline{\text { Rutinum }}+\underline{\text { Salicis cortex }]}$ or their middle parts e.g. Scorbolamid [Acidum ascorbicum + Salicylamidum]. Not rarely does the name of medicine end with the suffix -inum (often abbreviated to -in), meaning a substance, e.g., Rutinoscorbin (Rutinum + Acidum ascorbicum $+i n[u m])$. In the names of medicines there appear also words obtained by combining the name of a chemical agent and words or their stems borrowed from Latin in their full like vita, e.g., Ascorvita

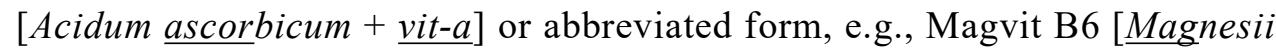

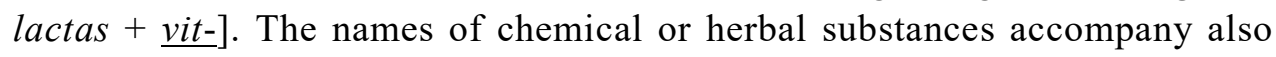
the names of organs, functions, conditions and diseases forming other composite words that are discussed below.

2. Trade names of medicinal products with the name of an organ in Greek or Latin

The trade names of medicines which make use of the Latin and Greek names of human organs are rarely simple words; more often than not, these are words including the full or shortened name of an organ and other components borrowed from Latin like adjectives, common Greek terms defining the medical problem, names of active substances present in a given medicinal product, or Polish words. Sometimes words found words formed

\footnotetext{
${ }^{13}$ On the multitude of rules used in Poland to transcribe names of medicines see: Krzysztof J. FiLIPIAK, "Polskie nazewnictwo leków-bałagan trwa...," Choroby Serca i Naczyń 3, no 1(2006): 52-57.
} 
by modifying a root or stem and affixation are found, e.g., Dermatol (a common name of Bismuth subgallate, which includes the Greek stem dermat- and the ending -ol, which in medicine signifies that the substance is a hydroxyl-derivative of a hydrocarbon, e.g., alcohol or phenol) or Otinum (in which the root ot-stands for the ear and -inum for the substance). These names of medicines may be divided into various categories: according to the name of an organ, their linguistic structure, or category of the accompanying components. For the purposes of this article, drug names have been ordered according to one particular component, i.e., the names of body parts in Latin and Greek which are recognizable and commonly used not only in pharmaceutical but also medical and cosmetic terminology. Here are just a few examples of different groups of medicines acting within:

- the head and its organs: Cefalgin, Oculobrim, Oculosan, Oftahist, Oftidor, Nasirus forte, Rhinazin, Buderhin, Otinum, Ototalgin, Sinumedin, Bobodent, Dentosept, Sulphodent;

— the circulatory system: Venoforton, Venolan, Venotonin, Venotrex, Venożel, Acard, Anacard medica protect, Bonacard, Cardiacol C;

- the digestive system: Alugastrin, Gastranin Zdrovit, Gastrosan, Gastrobonisol, Gastricon, Ranigast, Hepacynar, Hepatosan fix, Procto-Hemolan, Proctomina, Hemorectal, Enterosol;

— the excretory system: Urofort, Urosal, Urosan, Urosept, Nefrobonisol, Nefrosept;

— the respiratory system: Herbapect, Pectobonisol, Pectosol, Tussipect, Pulneo, Pulmonil, Bronchicum T, Bronchisan fix, Bronchosol; mosavit.

— the skin: Acne-derm, Baikaderm, Dermatol, Dermatol Aflofarm, Dermopanten, Der-

Among the names of medicines found in this group the most common components, besides body parts, among which there appear such organs as the head, eye, ear, nose, tooth, vein, heart, stomach, liver, anus and rectum, intestine, kidney, bladder, thorax, lungs, bronchi, skin, are the names of herbal or chemical active substances usually combined with the name of an organ as follows: the name of an organ and the beginning of the name of the

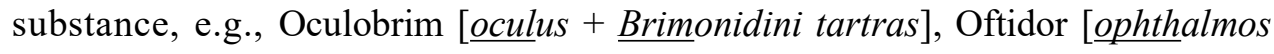
+ Dorzolamidum], Cardiacol C [kardia + Colae extractum fluidum], Hepacynar [hepar + Cynarae folii extractum siccum], Gastranin Zdrovit [gaster + Ranitidinum], or the name of an organ and the middle part of the name of a substance, e.g., Dermopanten [ $\underline{\operatorname{derm}} a+$ Dexpanthenolum $]$. Sometimes, there 
appear the opposite order of the words, in which the beginning or middle part of the name of the substance is followed by the name of an organ e.g. Buderhin [Budesonidum + rhin-], Alugastrin [Dihydroxyaluminii natrii carbonas + gaster $]$. Another representative group of components in this category of medicines include various Latin roots or stems of words with a particular meaning connected with health and well-being that serve to create many analogical names of medicines such as -san (healthy, to cure), e.g., Bronchosan, Oculosan, Hepatosan, Gastrosan; -sept (referring to the presence of infection, and here with a meaning of antiseptic), e.g., Dentosept, Urosept or Nefrosept; -bon- (good), e.g., Bonacard; -sol (solution) Gastrobonisol, Nefrobonisol, Pectobonisol, Enterosol, Pectosol, Bronchosol. There appear also Latin adjective like fortis, -e (strong), e.g., Venoforton or Urofort, which may suggest either the strength of the medicine or of the treated organ. The name of an ailment may also accompany the name of an organ in medicines' names e.g. Tussipect (tussis + pectus), Acne-derm, Ototalgin (ot- + algos + in $[u m])$, Cefalgin (kephale + algos + in $[u m]$ ), or the full or abbreviated name of the manufacturer is added to the name of an organ before e.g. Sulphodent $\left(\underline{\text { Sulphur }}{ }^{14}+\right.$ dent-) or after, e.g., Proctomina (proct- + Farmi$\left.n a^{15}\right)$. Rarely does the Polish component appear to form hybrid words, e.g., Bobodent ( $\underline{\text { bobo }}[\mathrm{baby}]+d e n t-)$ or Venożel $(\underline{\text { ven } a}+\dot{z} e l$ [gel]).

3. Trade names of medicinal products with the words describing functions, states and diseases

Some words that belong to this group were analysed earlier. Similarly to other discerned groups of names of medicinal products, in this one also single or composite words appear, referring to various medical problems and concerns. These names, despite Latin and Greek components, include various endings, English words or descriptive forms. The following groups of medicines may be distinguished with respect to various medical problems treated by the product such as medicamenta:

Digestiva: Digestiol, Digestonic

Antipyretica et anelgetica: Pyramidon (fast), Antidol 15, Pyralgina, Cefalgin

\footnotetext{
${ }^{14}$ SULPHUR ZDRÓJ from Busko-Zdrój is the only Polish manufacturer of medicines made from natural medicinal minerals: sulphide brine and peat water extract.

${ }^{15}$ Farmina is a pharmaceutical company that manufactures finished dosage form medicines. Its products cover a range of therapeutic areas including dermatological, analgesic, gastrointestinal, cardiovascular and gynaecological applications.
} 
Antiallergica: Acatar Zatoki (sinus), Allertec Ukąszenia (insect bites)

Antitussica: Apitussic, Dexatussin Junior (Dextromethorphani hydrobromidum), Flegatussin, Tussal Antitussicum, Tussal Expectorans, Tussipect

Dermatica: Acne-derm

Antiphlogistica: Cerugrip, FastGrip Hot, Gripblocker, Gripex (hot, max, control, hot zatoki [sinus], noc [night], sinu-caps, zatoki-caps)

Sedativa: Antinervinum, Nervinex-fix, Nervomix, Nervolek, Nervosan, Rhelax

Stomatica: Aphtin

Diabetica: Diabetofort.

The presented exemplary names of medicines are also composite words formed in a similar ways as the groups of names previously discussed in this article. Derivative forms are observed, e.g., Aphtin (aphtha + -in [inum]), Antinervinum (anti + nervus + inum $)$, Acatar $(a-+$ catarrhus $)$, Antidol (anti+ dolor); compound words such as Acne-derm (acne + derm-), Nervomix (nervus + mix), Apitussic (apis + tussis), Nervolek (nervus + lek [medicine]). Such endings as -icum (-ic) [belonging to, derived from, connected with], e.g., Apitussic, -in (- inum) [a substance], e.g., Pyralgina, Cefalgin, Dexatussin; san (healthy), e.g., Nervosan; fortis, -e (strong), e.g., Diabetofort are also very common in word-formation processes. It is worth mentioning here that also in this group English and Polish words appear as the components of the names of medicines like, e.g., lek (medicine), fast or blocker.

\section{LATIN AND GREEK VS POLISH}

As indicated above in many examples, Polish is hardly used in the names of medicinal products. There appear very few examples of such words and they are usually added as a descriptive element written below the trade name or even more seldom as a part of the name itself. The reason is obvious as medicines are produced and aimed to reach international market, so the names must be easy to read and remember. As Latin and Greek underlie many modern languages, including English, and make the language of modern medicine, it is reasonable to refer to ancient roots that should be obvious and understood everywhere. The features of Polish vocabulary with its Polish characters, difficult pronunciation and local nature make it impossible to apply these words, save for products distributed only in the Polish market. For this reason. the list of medicinal products approved by Polish authorities includes such names as: Venożel, Hydrożel, Zatogrip. Polish words appear also as extra information printed below the trade name, e.g., zatoki (sinus), 
ukąszenia (insect bites), bez cukru (sugarfree), noc (night), nos (nose), przeziębienie (flu) or kaszel (cough) to make the consumer associate the product with a particular type of body part or action. Another example of Polish terminology in the names of medicinal products is the word 'bobo' (baby), which is easy to pronounce and remember, e.g., Bobotic, Bobodent.

On the other hand Polish is used instead of Latin, Greek or English in descriptive names, which refer to old recipes, commonly known and used in the past. The companies resort to old-fashioned names when they want either to indicate the purpose of the product, e.g. Krople nasercowe (heart drops), Krople żołądkowe (stomach drops), Maść na odciski (corns ointment ), Tabletki przeciw grypie (flu tablets), Tabletki przeciw niestrawności (adigestion tablets), Tabletki przeczyszczające (laxative tablets), Tabletki uspokajające (calming tablets), Pastylki wykrztuśne (expectorant tablets), or to describe the form and the active substance present in a particular medicinal product, e.g. Maść arnikowa (Arnica ointment), Maść borowinowa z mentolem (mud ointment with menthol), Maść ichtiolowa (ichthyol ointment), Maść z tlenkiem cynku (zinc oxide ointment), Olej rycynowy (castor oil), Olejek sosnowy (pine oil), Pasta cynkowa (zinc paste), or Tabletki z czosnku (garlic tablets).

\section{IS THE NAME ALWAYS RIGHT?}

If we analyse the pharmaceutical market, especially the brand names of medicines distributed and sold in Poland, it is worth studying different internet pharmaceutical fora ${ }^{16}$ to find out which names achieved the assumed goals and which did not, as the name failed to become a part of common memory of patients. Some names tend to be mistaken and misassociated, e.g., Renopuren which operates within the nose and sinus, not kidneys. This trade name may be in some way misleading, as it does not follow the general rules indicated in the Announcement of the President of the Office for Registration of Medicinal Products, Medical Devices and Biocides from March 12, 2008. The inventors' imagination and ability to make still new words basing on the same stems for two thousand years is a kind of art. Among the

\footnotetext{
${ }^{16}$ See also Samuela TOMASIK, "Pomyłki apteczne. O niezamierzonych przekształceniach nazw handlowych leków," in Konvergencie a divergencie v propriálnej sfére. 20. slovenská onomastická konferencia Banská Bystrica 26.-28. júna 2017. Zbornik referátov, eds. Alexandra Chomová, Jaromír Krko, Iveta Valentová (Bratislava: VEDA. Vydavatežstvo Slovenskej akadémie vied, 2019), 451-458.
} 
names that evoke Latin or Greek and are pleasant to the ear, easy to remember and indicate more or less the effects, are: Hypnomidate (hypno + etomidatum), Kreon travix (pancreas + trawić), Perceptin (percipio, ere), Depresanum, Pedipur (pes, pedis + purus), Revitanerw, Revitasens.

\section{CONCLUSIONS}

As we have demonstrated above, Latin and Greek still seem an inexhaustible source of linguistic components applied in word-formation processes, especially in medicine. The names of natural ingredients, chemical substances, body parts, diseases and a host of adjectives and other parts of speech are often used in the names of medicinal products, in chemical, international and above all in the trade names of medicines.

In the trade names of medicinal products there appear also other, not discussed here but worth mentioning, words of Latin and Greek origin describing various aspects like: the target patient group (e.g., junior, senior, geria-, -gyn-, -femin- ${ }^{17}$ ), effectiveness (rapid, max, forte, acti-, bon- ${ }^{18}$ ), intensity (forte, mite, active, intensive max, plus, optima, multi, pan $^{19}$ ) and others such as e.g. termo, hydro-, api-, flos, nutri, but also English words like: hot, fruit or rarely Polish, e.g., noc, dzień.

Of course, apart from the trade name itself, there are also other elements that are decisive in the product's marketing success, like visuality and commercial expenses, but a successful trade name is absolutely crucial and therefore nowadays inventing still new names for similar products became a kind of art, where Latin and Greek make still an inevitable part.

\section{BIBLIOGRAPHY}

BREZA, Edward. "Nazwy obiektów i instytucji związanych z nowoczesną cywilizacją (chrematonimy)." In Polskie nazwy własne. Encyklopedia, edited by Ewa Rzetelska-Feleszko, 343-361. Warszawa-Kraków: Wydawnictwo Instytutu Języka Polskiego PAN, 1998.

Chrematonimia jako fenomen wspótczesności, edited by Maria Biolik, Jerzy Duma. Olsztyn: Wydawnictwo Uniwersytetu Warmińsko-Mazurskiego, 2011.

\footnotetext{
${ }^{17}$ Today, English forms are starting to prevail, such as: baby, kids.

${ }^{18}$ In these forms, English also seems to be the most prevalent, e.g., fast, ultra-fast, express, sprint, effect although most of these words derive from Latin and Greek stems.

${ }^{19}$ In these forms also English seems very common e.g. active, intensive, etc., although most of these words derive from Latin and Greek.
} 
CIEŚLIKOWA, Aleksandra. "Jakie korzyści daje onomastyce chrematonimia?" In Chrematonimia jako fenomen wspótczesności, edited by Maria Biolik and Jerzy Duma, 113-123. Olsztyn: Wydawnictwo Uniwersytetu Warmińsko-Mazurskiego, 2011.

FABris, Giampaolo, and Laura Minestroni. Valore e valori della marca. Come costruire e gestire una marca di successo. Milano: Franco Angeli, 2004.

FiliPIAK, Krzysztof J. "Polskie nazewnictwo leków_bałagan trwa..." Choroby Serca i Naczyń 3, no 1(2006): 52-57.

Funkcje nazw własnych $w$ kulturze i komunikacji, edited by Irena Sarnowska-Giefing, Mieczysław Balowski, Magdalena Graf. Poznań: Instytut Naukowo-Wydawniczy “Maiuscula,” 2015.

GAŁKOWSKI, Artur. “Chrematonimia w kulturze współczesnej.” Onomastica 61, no 1(2017): 55-71.

GAŁKOWSKI, Artur. "Funkcja marketingowa chrematonimów w przestrzeni gospodarczej." In Funkcje nazw własnych $w$ kulturze $i$ komunikacji, edited by Irena Sarnowska-Giefing and Mieczysław Balowski and Magdalena Graf, 171-180. Poznań: Instytut Naukowo-Wydawniczy "Maiuscula," 2015.

GAŁKowski, Artur. Chrematonimy w funkcji kulturowo-użytkowej. Onomastyczne studium porównawcze na materiale polskim, włoskim, francuskim. Łódź: Wydawnictwo Uniwersytetu Łódzkiego, 2008.

Gangwal, Amit. "Naming of Drug Molecules and Pharmaceutical Brands." Accessed: April 29, 2019. https://www.pharmatutor.org/articles/naming-of-drug-molecules-and-pharmaceutical-brands.

ŁYSOŃ, Piotr. Zdrowie i ochrona zdrowia w 2011 roku. Warszawa: Zakład Wydawnictw Statystycznych, 2012.

TomAsik, Samuela. "Onomastyka w służbie zdrowiu, czyli o nazwach handlowych leków. Rekonesans badawczy.” Acta Onomastica 54(2013): 256-271.

TOMAsiK, Samuela. "Pomyłki apteczne. O niezamierzonych przekształceniach nazw handlowych leków.” In Konvergencie a divergencie v propriálnej sfére. 20. slovenská onomastická konferencia Banská Bystrica 26.-28. júna 2017. Zbornik referátov, edited by Alexandra Chomová, Jaromír Krko, Iveta Valentová, 451-458. Bratislava: VEDA. Vydavatežstvo Slovenskej akadémie vied, 2019.

WALKowiak, Justyna Barbara. "Foreign branding in Poland. Chrematonyms and Anthroponyms." Proceedings of ICONN 2(2013): 218-227.

\section{ŁACINA I GREKA W ŚWIECIE WSPÓŁCZESNEGO NAZEWNICTWA FARMACEUTYCZNEGO W POLSCE}

\section{Streszczenie}

Celem artykułu jest ukazanie, że słowa pochodzące z łaciny i greki są nadal efektywnie wykorzystywane w polskiej terminologii farmaceutycznej na przykładzie nazw handlowych leków oraz form, w jakich owe terminy pojawiają się w interesującym autora nazewnictwie. Autor pracy definiuje pewne zauważalne i charakterystyczne paradygmaty pojawiania się form łacińskich i greckich, które występują w konkretnych wyodrębnionych w artykule grupach leków, wskazuje na pewne widoczne tendencje w zastosowaniu języków innych niż klasyczne oraz podkreśla, jak ogromne znaczenie ma łacina i greka w ciągle rozwijającym się polskim przemyśle farmaceutycznym.

Słowa kluczowe: leki; nazewnictwo; farmacja; łacina; greka. 


\section{LATIN AND GREEK IN CONTEMPORARY NAMES OF HUMAN MEDICINES ON THE POLISH MARKET}

Summary

The aim of the article is to show that Latin and Greek derived words are still effectively used in Polish pharmaceutical terminology. The study focuses on the trade names of medicinal products and the forms in which these terms appear in the above mentioned nomenclature. The author defines some noticeable and characteristic paradigms of the presence of Latin and Greek forms that occur in specific groups of medicines identified in the article, points to some visible trends in the use of non-classical languages and emphasizes the importance of Latin and Greek in the evergrowing Polish pharmaceutical market.

Key words: medicines; names; pharmacy; Latin; Greek. 